\title{
Investigation on the Employment of Ex-Soldiers in Physical Education Major in Colleges and Universities
}

\author{
Zongshao Wang \\ College of Physical Education and Health Science, Zhejiang Normal University, Jinhua, China \\ Email:616970154@qq.com
}

How to cite this paper: Wang, Z.S. (2021) Investigation on the Employment of Ex-Soldiers in Physical Education Major in Colleges and Universities. Open Access Library Journal, 8: e7668.

https://doi.org/10.4236/oalib.1107668

Received: June 21, 2021

Accepted: July 10, 2021

Published: July 13, 2021

Copyright $\odot 2021$ by author(s) and Open Access Library Inc.

This work is licensed under the Creative Commons Attribution International License (CC BY 4.0).

http://creativecommons.org/licenses/by/4.0/

\begin{abstract}
In order to further improve the research content of retired soldiers college students in various aspects of employment, enrich the theoretical system of the employment status of retired soldiers, and achieve the purpose of guiding the employment of retired college students, this paper takes Physical Education College of Luoyang Normal University as the research object. By using the methods of literature review, mathematical statistics and personal interview, this paper studies the job satisfaction and employment area of retired soldiers after graduation in Physical Education College of Luoyang Normal University.
\end{abstract}

\section{Subject Areas}

Physical Education

\section{Keywords}

Retired College Students, Employment Status, Professional Skills, Retired School, Sports

\section{Introduction}

Ex-soldiers and college students (hereinafter referred to as "ex-soldiers") refer to college students who temporarily suspend their studies and join the army, and then return to school to complete their studies after being discharged from the army [1]. In order to further promote the deepening reform of the army, accelerate the modernization of national defense and the army, and realize the dream of a strong army, the employment of retired university students is the key for China to continuously attract talents from universities and improve the quality 
of the construction of military personnel [2]. As the country attaches more and more importance to the retired soldiers, the employment of the retired soldiers as a group of university students has become an urgent problem to be solved. In this paper, through the investigation and research on the employment situation of retired soldier college students in the past five years, we know the employment development direction of retired soldier college students in Physical Education College of Luoyang Normal University, and finds that there are still some problems in the career choice and employment direction of retired soldier college students, which requires the university to provide more support for the choice of employment direction of retired soldier college students in combination with the needs of social development. It aims at the employment development direction of the retired soldiers and college students majoring in sports, as well as the expectation of their own career and employment and other related fields, so that students can better face the pressure of career competition.

\section{Research Objects and Methods}

\subsection{Respondents}

Graduates of 2013, 2014, 2015, 2016 and 2017 are retired soldiers of Luoyang Normal University majoring in physical education.

\subsection{The Research Methods}

\subsubsection{Data Documentation Method}

Refer to the relevant books and search CNKI above the relevant paper data, and then collect the relevant graduate employment information, for the completion of the paper to lay the data support and theoretical support.

\subsubsection{Interview Method}

In the past five years, three ex-soldiers from 2013, four from 2014, five from 2015, five from 2016 and six from 2017 majoring in physical education have been consulted in detail about the employment field, current status of career development and related issues.

\subsubsection{Questionnaire Survey Method}

In order to make the survey results more real and effective, the author elaborately designed questionnaire questions, issued online questionnaires and collected them from qualified ex-soldiers and college students of Grade 2013-2017 of Physical Education Institute, and conducted interviews and understandings by using WeChat information and telephone consultation. Veterans and college students have frequent communication with the WeChat group, and it is relatively convenient to understand the communication channels. The actual number of effectively collected questionnaires was 23 .

\subsubsection{Mathematical Statistics}

In this paper, Excel2020 software is used to make mathematical statistics on the career development, career satisfaction and effective information data of retired 
sports major college students in Luoyang Normal University, and to summarize the research content of this paper, and make scientific analysis on the statistical data.

\section{Research Results and Discussion Analysis}

\subsection{Investigation and Analysis on the Occupational Status of the Retired Soldiers in the Physical Education Major in Colleges and Universities}

\subsubsection{Investigation and Analysis of Employment Percentage of Ex-Soldier College Students in Physical Education Institute}

Through the analysis of the employment percentage of retired soldiers and college students majoring in physical education in the above universities (Table 1), it is found that there are 3 ex-soldiers and college students in the class of 2013 who have good career development, 4 ex-soldiers and college students developed their own careers in 2014, 5 ex-soldiers and college students participated in the work in 2015 and 2016 respectively. And for the class of 2017, 6 ex-soldiers and college students participated in the work, accounting for $13 \%, 17 \%, 21.7 \%$, $21.7 \%$ and $26 \%$ of the total number in the survey respectively [3].

\subsubsection{The Conclusion and Research on the Employment Tendency of Ex-Soldiers Majoring in College Physical Education}

According to the data analysis obtained in Table 2, there are 5 graduates who have excellent military quality and take advantage of their discipline and specialty to engage in the fitness coach industry. Graduates who take professional ball coaches as their career development are mainly concentrated in regions and cities with better development. The choice of boxing professional field is very promising, based on Chinese traditional martial arts, carry forward China's national excellence. As retired graduates, there are not a few who are engaged in recruitment and teaching examination after graduation, accounting for $34.8 \%$. As a special group of retired college students, there will be preferential policies when applying for the examination. As for the entrance examination for postgraduate studies, the number of students is increasing year by year. Moreover, the promulgation of "Ex-graduates and Soldiers Special Postgraduate Recruitment Plan" has greatly reduced the difficulty for ex-soldiers to be admitted for

Table 1. Statistical results of employment percentage of retired soldiers majoring in sports from 2013 to 2017.

\begin{tabular}{ccc}
\hline Grade & Percentage of employment & Number of workers \\
\hline 2013 class & $100 \%$ & 3 \\
2014 class & $100 \%$ & 4 \\
2015 class & $100 \%$ & 5 \\
2016 class & $100 \%$ & 5 \\
\hline
\end{tabular}


2017 class

$100 \%$

6

Table 2. Employment tendency of ex-soldiers majoring in physical education in colleges and universities from 2013 to 2017.

\begin{tabular}{|c|c|c|c|c|c|c|c|}
\hline $\begin{array}{l}\text { Employment } \\
\text { tendency }\end{array}$ & Fitness trainer & Teachers & Civil servants & $\begin{array}{c}\text { Basketball, } \\
\text { football and } \\
\text { other ball games }\end{array}$ & $\begin{array}{c}\text { Take part in the } \\
\text { postgraduate } \\
\text { entrance exams }\end{array}$ & $\begin{array}{c}\text { All kinds of } \\
\text { boxing classes }\end{array}$ & other \\
\hline 2013 class & 1 & 0 & 0 & 1 & 0 & 0 & 1 \\
\hline 2014 class & 1 & 1 & 1 & 0 & 0 & 1 & 0 \\
\hline 2015 class & 2 & 1 & 1 & 0 & 1 & 0 & 0 \\
\hline 2016 class & 1 & 1 & 0 & 1 & 2 & 0 & 0 \\
\hline 2017 class & 0 & 1 & 0 & 0 & 5 & 0 & 0 \\
\hline$\%$ & $21.7 \%$ & $26 \%$ & $8 \%$ & $8 \%$ & $34.8 \%$ & $4 \%$ & 0 \\
\hline
\end{tabular}

postgraduate studies [4]. With the development of recent years, a new sports industry, young children's physical intelligence coach appears in the field of vision of students, which is on the rise to the development of the industry. Others include very few related industries that engage in related sports.

\subsubsection{Investigation and Analysis of Employment Satisfaction of Ex-Soldier Graduates}

As shown in Table 3, twenty-three people were effectively investigated, and 69.5\% of them were satisfied with the survey, mainly focusing on the direction of fitness and sports coach industry and sports teaching graduate students. $26 \%$ said they were satisfied, mostly with teachers and other freelance professions. There are $4 \%$ people think average, mainly including independent choice of career industry.

As shown in Table 4, through effective investigation and inquiry, it is known that graduates of ex-soldiers who stay in first-tier cities after graduation, such as Beijing, Shanghai, Guangzhou and other places with good economic development, are greatly influenced by their career choice. Their career field is fitness, and there are relatively many students who choose to take postgraduate entrance exams, mainly distributed in the coastal areas. The retired graduates are generally mature in thought, while the retired graduates are the main choice in the provincial capitals. Students in small and medium-sized cities have a more suitable choice. They can choose professional posts by participating in the recruitment of local urban civil servants in the place where their household registration is located. Rural majority of the choice of special Gang, recruit teaching examination when teachers.

\subsection{Analysis of Factors Affecting Employment of Ex-Soldiers in Colleges and Universities}

1) Social factors. Strong sports make a country strong. In the new period, the construction of a strong sports country is the direction of the reform and devel- 
opment of China's sports work. Now more and more people have more urgent needs for health.

Table 3. Statistics on employment satisfaction of graduates from 2013 to $2017(n=23)$.

\begin{tabular}{cccc}
\hline Satisfaction & Satisfied with the & Satisfied & General \\
\hline 2013 class & 2 & 1 & 0 \\
2014 class & 3 & 1 & 0 \\
2015 class & 3 & 1 & 1 \\
2016 class & 3 & 2 & 0 \\
2017 class & 5 & 1 & 0 \\
$\%$ & $69.5 \%$ & $26 \%$ & $4 \%$ \\
\hline
\end{tabular}

Table 4. Statistics of occupation region of ex-soldiers majoring in physical education in colleges and universities from 2013 to 2017.

\begin{tabular}{ccccc}
\hline & $\begin{array}{c}\text { Economically } \\
\text { developed } \\
\text { first-tier cities }\end{array}$ & $\begin{array}{c}\text { The provincial } \\
\text { capital city }\end{array}$ & A small city & rural \\
\hline 2013 class & 2 & 0 & 1 & 0 \\
2014 class & 1 & 2 & 0 & 1 \\
2015 class & 2 & 1 & 1 & 1 \\
2016 class & 1 & 3 & 2 & 0 \\
2017 class & 0 & 2 & 4 & 0 \\
Number of people & 6 & 8 & 8 & 2 \\
$\%$ & $26 \%$ & $34.7 \%$ & $34.7 \%$ & $17.3 \%$ \\
\hline
\end{tabular}

2) Influence of curriculum setting. The combination of the curriculum setting of college physical education and the development of social physical education needs to be solved. The current social development changes with each passing day, the setting of school physical education curriculum should follow the pace of the development of The Times.

3) Personal quality factors. With the development of economic globalization, students do not know enough about the severity of the current employment situation. There is a great distance between career choice and geographical development.

\section{Conclusions and Suggestions}

\subsection{Conclusions}

1) The vocational development of former soldiers and college students who successively participated in the work in the recent five years in the School of Physical Education of Luoyang Normal University is greatly affected by social environmental factors and personal quality. 
2) Through research and analysis, it is found that with the improvement of people's material life, the development of sports industry has been booming in recent years. The former soldiers and graduates combine their majors, mainly in the direction of fitness and bodybuilding, ball games (mainly football) and other sports directions. In today's modern economy with rapid development, sports professionals have a bright career prospect in today's prosperous economic society.

3) Although the government provides a lot of preferential policies for ex-college soldiers to participate in work, such as participating in the examination of political and legal police officers, the examination of public institutions, and the fixed-point recruitment plan for civil servants, the employment channels for ex-college students are single [5]. Retired soldier college students have high political consciousness, strict sense of discipline and strong sense of overall situation. However, some of them can not complete the teaching task well when they apply to be teachers after graduation, such as they cannot use flexible methods to manage and educate students, cannot well practice the concept of "teacher led, student-centered" and obviously lack of teaching experience [6].

4) The four-year university training mode needs to be further optimized and improved. During the study period, courses such as professional quality, career planning and taekwondo should be added to students. The employment problem and market supply and demand should be further improved to give full play to the teaching function of physical education [2]. Based on the concrete analysis of students' actual situation and specific problems, specific plans that can be implemented should be proposed accordingly.

\subsection{Recommendations}

1) As a contemporary college student to join the army, to serve the motherland, dedicated to national defense, this is a glorious mission and far-reaching significance. The Party and the state should attach great importance to it, and governments at all levels and universities should further strengthen the degree of policy preference, such as giving priority to party membership, selection, awards and grants during school [5]. Secondly, the highly qualified ex-soldiers who have been trained in the army should be good at training and using them, so that the ex-soldiers and college students can give full play to the skills they have learned in the army and carry forward the fine tradition in the army to the school. Students create a retirement party organization of the event, to retire the soldier college students in the school of "family" feel the warmth of the organization, will be retired resumption and ready to join the army schooling students organized, build a platform, keeping the notion of war do not fade, joined the army in the future university students help recruits students avoid detour little detours.

2) Youth without regret, with pen to serve the motherland, the former soldiers and college students after the end of military service, most of the college students 
choose to go back to further education, or graduate school entrance examination. The university should reasonably allocate the corresponding employment platform, guide the ex-soldiers' college students to base on the development direction of their major, combine with the two-year military experience, innovate the concept of employment, and realize the multi-channel and high-quality employment [7]. Increase employment channels to provide more convenient employment paths and opportunities for ex-soldiers and college students. The university builds a new employment platform and opens a "green channel" of employment for the special group of ex-soldiers and college students, so as to better promote the employment of ex-soldiers and college students.

3) Down to earth, look up at the stars. Ex-soldiers college students should be based on their major step by step to learn the knowledge well and solid, set up a high goal, interdisciplinary learning. College physical education majors keep up with the pace of the development of The Times, combined with the need of social reality development, by establishing a cooperative mechanism with local schools to provide students with exercise opportunities and increase practical experience. Open more fitness related courses that have developed well in recent years, such as increasing the study of other boxing such as taekwondo. In school, PE teachers should cultivate students' practical ability and increase the practice of teaching method so as to cultivate applied talents who are fully developed by combining theory with practice.

4) Soldiers are the most important thing in the country. The good placement of ex-soldiers is not only related to the interests of ex-college soldiers, but also closely related to the construction of China's national defense and army. If a country wants long-term peace and stability, it must start with the construction of a strong army [8]. In the same way, the employment of ex-soldiers and college students can better attract college students to join the strong army and lay a foundation for the realization of national defense modernization, thus forming a virtuous circle.

\section{Conflicts of Interest}

The author declares no conflicts of interest.

\section{References}

[1] Zhu, J. (2015) From Army Gate to School Gate: Study on Veterans Rehabilitation Colleague Students' Adaptability Problems-Take Wuxi J University as an Example. Master Thesis, Jiangnan University, Wuxi.

[2] Zhang, Z. (2017) The Issue and Countermeasure on Conscription-Based on the Investigation in Henan Province. Master Thesis, Henan University of Technology, Zhengzhou.

[3] Chen, Y. and Zhang, F. (2018) The Research on the Development and Obtain Employment Situation of College Student Soldiers-Taking the University of Science and Technology Beijing as An Example. China University Students Career Guide, 20, 54-58.

[4] Zhang, L. (2019) The Research and Enlightenment of American Veterans' Educa- 
tional Assistance Strategies. Master Thesis, Hebei Normal University,, Shijiazhuang.

[5] Liu, K. (2020) Comparative Study on Employment Priority of Veterans between China and the United States. Chinese Personnel Science, 3, 87-95.

[6] Liu, Y. (2019) Study on the Transition Process of Retired Soldier's Vocational of Roles-Based on In-Depth Interviews with 13 Retired Soldiers. Master Thesis, East China University of Science and Technology, Shanghai.

[7] Jiang, L. and Miao, X. (2021) Research on the Employment and Entrepreneurship of Retired College Students. Journal of Shenyang Institute of Engineering (Social Science Edition), 17, 130-134. (In Chinese)

[8] Xu, Z. (2011) A Study of Influencing Factors on Growth and Success of College Student Soldier. Master Thesis, National University of Defense Technology, Changsha. 